ARTIGO

COIttps://doi.org/10.22481/praxisedu.v15i34.5807

\title{
THE POTENTIAL IMPLEMENTATION OF A FREE TRADE AREA ON A TWO- SIDED AND MANY-SIDED
}

\author{
LA IMPLEMENTACIÓN POTENCIAL DE UN ÁREA DE LIBRE COMERCIO EN UNA \\ Y DOS CARAS
}

\section{A POTENCIAL IMPLEMENTAÇÃO DE UMA ÁREA DE LIVRE COMÉRCIO EM AMBOS OS LADOS E EM VÁRIOS LADOS}

\author{
E.S. Sokolova \\ University under the Government of Russian Federation - Russia \\ V.V. Perskaya \\ University under the Government of Russian Federation - Russia \\ A.A. Tkachenko \\ University under the Government of Russian Federation - Russia \\ P.V. Alekseev \\ University under the Government of Russian Federation - Russia \\ M.A. Rylskaya \\ University under the Government of Russian Federation - Russia
}

\begin{abstract}
Resumo: $\mathrm{O}$ artigo é dedicado à análise da potencial implementação de áreas de livre comércio (TLC) em dois lados e em vários lados e os principais problemas de desenvolvimento das relações econômicas entre a União Econômica da Eurásia (EAEU) e a República Socialista do Vietnã (SRV). A análise do comércio exterior entre os países da EAEU e o Vietnã é realizada com base no modelo de gravidade do autor, que pode ser usado para analisar o desenvolvimento de conexões de comércio exterior entre a EAEU e outros países. De acordo com o modelo de gravidade do autor, está provado que o Acordo de Livre Comércio é um instrumento bastante eficaz para o desenvolvimento das relações comerciais entre os países.
\end{abstract}

Palavras-chave: Área de livre comercio; Acordo sobre livre comercio; Investimentos estrangeiros diretos; Comércio exterior de mercadorias e serviços.

Abstract: The article is devoted to the analysis of the potential implementation of free trade areas (the FTA) on a two-sided and many-sided basis and main problems of development the economic relations between the Eurasian Economic Union (the EAEU) and the Socialist Republic of Vietnam (the SRV). The analysis of the foreign trade between countries of the EAEU and Vietnam is fulfilled on the base of author's gravity model which can be used for 
analysis the development of foreign trade connections between the EAEU and other countries. According to the author's gravity model it is proved that the Free Trade Agreement is a quite effective instrument for development trade relations between countries.

Keywords:The free trade area; Agreement on free trade: Direct foreign investments; Foreign merchandise and services trade.

Resumen: El artículo está dedicado al análisis de la implementación potencial de las áreas de libre comercio (TLC) sobre una base doble y múltiple y los principales problemas de desarrollo de las relaciones económicas entre la Unión Económica Euroasiática (EAEU) y el República Socialista de Vietnam (la SRV). El análisis del comercio exterior entre países de la EAEU y Vietnam se realiza sobre la base del modelo de gravedad del autor que puede usarse para analizar el desarrollo de las conexiones de comercio exterior entre la EAEU y otros países. Según el modelo de gravedad del autor, se demuestra que el Tratado de Libre Comercio es un instrumento bastante efectivo para las relaciones comerciales de desarrollo entre países

Palabras clave: Área de libre comercio; Acuerdo sobre libre comercio; Inversiones extranjeras directas; Comercio exterior de mercancías y servicios.

\section{Introduction}

After the USA withdrew from the Agreement on Trans-Pacific Partnership (the TPP) according to American sources there was a dilemma for Vietnam in terms of stimulating its foreign trade in the framework of the Asia-Pacific Region (the APR). It is in the fact that for further development of Vietnam's export a maximum liberalization of foreign trade regime is necessary in order to compensate the TPP organically. From the point of view of Hanoi, the TPP was ideal for attracting foreign investments and for developing an export. It has a decisive meaning for providing and for overcoming the competition in the APR and at the same time for supplying a gradual reforming of Vietnam's economy. According to American experts, nowadays there is a great amount of ineffective government enterprises that mostly form a gross national product in Vietnam (Douglas, 2017).

In spite of preservation a socialist country orientation, Vietnam realizes a liberal policy in the sphere of trade that implies the intensification of foreign trade cooperation within the framework of Agreements on the free trade not only with the Eurasian Economic Union but also with European Union. However, standards that are acceptable for the EU according to experts of the USA and the EU do not suit the policy of standardization within the framework of the EAEU. At the same time the orientation of Vietnam to the Eurasian Economic Union 
countries does not suit to the policy of optimization the process of reforming in Vietnam in terms of increasing the effectiveness of production, decreasing the capital-intensiveness and increasing the productivity of labour because the EAEU countries need such a reforming themselves. In this connection there is a certain scepsis in Vietnam in the evaluation of potential the Agreement on the free trade area with the EAEU countries stirred up by the media that support neoliberal interpretation of globalization.

In this regard the Western countries offer Vietnam to make a relevant Free Trade Agreement with the EU or China limiting and regulating the influence of Beijing on Vietnamese economy without intensifying the interaction with the EAEU countries (Lee \& Tseng, 2016). There is a thought that development of trade and economic partnership with the EU and the Free Trade Agreement with the EU will expand Vietnam's access to other markets and as a result it will reduce the dependence of Vietnam's economy on Chinese production.

The deepening of Vietnam's integration into the world economy in the conditions of the development of globalization processes made it vulnerable to the volatility of world markets at the same time displacing Vietnamese producers from Vietnam's domestic market.

Growing protectionism in the USA and the EU (the largest markets of Vietnam's export) is a negative sign of economic prospects for using the advantages of globalization by Vietnam. It is especially reflected on privatization of property in Vietnam, on the most important industries of Vietnam which are agriculture, steel and electronic production. Vietnam has joined the global chains of added value production but its part is not very big as the import of components for merchandise and services' export plays a significant role. Vietnamese export is vulnerable both in terms of possibilities of foreign partners to use production and in terms of possibilities to block the import of components by western partners. Moreover, the challenges are macroeconomic problems of Vietnam including a fragile banking system, an excessive number of "not working loans", weak rules of national regulation of economy and an absence of government enterprises' reforms and also a continued volatility of world prices in commodity and financial markets.

These difficulties motivate Vietnam to seek to diversification of its economic interaction that reflects the coming into force the Agreement "On Free Trade" between the EAEU and Vietnam that can be referred to the type of agreements on the FTA+. The specific nature of these types of agreements is in the fact that it includes not only the sphere of foreign merchandise and services trade but also issues of mutual usage of direct investments, tourism and other spheres of national economies. 
At that it is typical that such agreements leave all important and strategic development issues of participating countries within the national field of regulation at the same time coordinating the policy in the spheres of mutual interests.

The aim of the article is to analyze the potential implementation of the FTA on a twosided and many-sided basis and the key development issues of economic relations of the EAEU and the SRV.

The practical significance of the article is in working out practical recommendations for development of cooperation between the EAEU and Vietnam in the framework of the Agreement "On Free Trade" based on the analysis of potential implementation of the FTA on a two-sided and many-sided form and econometric modeling of trade flows between participating countries of the Agreement.

The contribution of this work to the science of the world economy is in the usage of the gravity model for analyzing and forecasting foreign trade flows of participating countries of the Free Trade Agreement between the EAEU and Vietnam.

\section{Research Methods}

Methodology of the research includes general and special methods of experience, an empiric approach to find out specifics of modern development of economic partnership processes, a current and prospective analysis and synthesis of theoretical and practical materials with building an econometric gravity model.

\section{Literature Review}

Different tools can be used for formalization and analysis of development of integration processes in foreign trade. One of the approaches is to use integral models taking into account various factors that appear while making integration connections between participating countries. Among factors are geographical location (Ludema, 2002; Baier, Bergstrand, 2007), presence of different preferences (Moser, Rose, 2014), presence of restrictions (Amiti, Romalis, 2006; Gallagher, 2008). As a rule the development processes of integration connections between countries with the same level of economic development are investigated with the help of such models. 
No less widespread are statistic network models describing pairwise cooperation of countries, strategies of interaction on which parameters of current period depend (Goyal, Joshi, 2006). On the base of such a model, scientists Xuan-Wei Li and Huan-Kai Tzen ("Preference of global free trade: models of joint network of free trade" on September 30, 2016) viewed a mechanism of interaction among countries in the conditions of global free trade area by setting priorities in forming trade relations with chosen group of partners. Their researches show that there is a vector of integration development from preferential trade agreements with separate countries to create many-sided free trade area which is provided by global institutions (such as the World Trade Organization - the WTO).

It is known that mathematical instrument describing foreign trade relations are gravity models that allow to model and analyze the development of trade flows between countries by using large files of statistic data that increase the precision of results. These models have great advantage in comparison with other models for our research as they allow to take into account the dependence of trade flows volume from the size of country's economy (the indicators of the Gross Domestic Product - the GDP).

The presence of fictitious variables in a model that take different values let reflect the fact of countries' participation in various trade agreements especially the Free Trade Agreement, a common border, a common language, common currency and other important aspects of foreign trade activity.

\section{The Analysis Of The Potential İmplementation Of A Free Trade Area On A Two-Sided And Many-Sided Basis}

The analysis of the potential implementation of a free trade area on a two-sided and many-sided basis is a science problem in the conditions of development the integration processes in the foreign trade activity and in particular the Free Trade Agreement between the EAEU countries and Vietnam.

This agreement is directed to work out mutual obligations by the participants to simplify the access to markets of their own countries in the framework of mutual trade for merchandise and services providers from partner-countries under the agreement.

At the same time the agreement on creation the free trade area is characterized as "Free Trade Area+" as it covers all directions of trade and economic cooperation. Except reduction of rate imported custom duties it also covers the directions of cooperation in the sphere of 
sustainable development, the obligations for right protection on the objects of intellectual property and for development of e-commerce, the sphere of state procurement and common principles of fair competition.

The presence of such type of agreement heightens the predictability for partnercountries of trade regulation as it obliges them to inform each other beforehand about changes in trade regulation, in using trade regimes, etc. It implies more profound synchronization of custom service activity and regulative institutions in the sphere of technical, sanitary and phytosanitary regulation and control.

Symptomatically, the Agreement provides obligations with mutual liberalization of trade in services, realization of investment cooperation and movement of individuals.

The signing of this agreement opens favorable opportunities for businessmen of the EAEU to enter the Vietnamese market (the population of the country is about 90 million people) and to enter the markets of other countries of the ASEAN and Asian regions on the whole by developing cooperative production with Vietnamese companies in Vietnam continuing traditions from the Soviet times but qualitatively at a different level.

For the Free Trade Agreements it is typical that their amount especially in the APR has a tendency to grow as a "chain reaction". It is explained by the process of liberalization of foreign trade that gives essential advantages to export and import countries. If there is a tendency to sign new free trade agreements in the APR or the FTA (or the FTA+), competitors begin to feel fear that somebody gets advantages in realization of the foreign trade potential and they lobby at the level of the governments to start negotiations on concluding the free trade agreements. Thus experts from the PRC say that the easiest way to stop discrimination is to sign the FTA with other countries. In other words there is a "domino effect" in the APR in the development of agreements on the FTA.

For example, China's agreements on development of the FTA with Japan and the Republic of Korea (the Far Eastern FTA defined by China) will stimulate economic growth on extra 0,33 per cent. Negotiations on the FTA between China and Australia lasting for several years because of problems with agriculture of Australia and disagreements around investment's access should lead to mutually beneficial growth of foreign trade of both countries.

Last decade there was a tendency to conclude mega-regional agreements in the world trade. First, they were directed to transform the existing international legal norms on manysided base and by that to reform the WTO Agreements. Secondly, they were directed to the maximum great number of countries located in various regions of the world community. It is 
about the Chamber of Commerce and Industry (the CCI) and the Comprehensive Regional Economic Partnership (the CREP) in the APR. Nowadays the first one is stopped because of the USA's withdrawal from it. The USA was an initiator of it and brought its law-enforcement practice significantly changing imperatives of international economic cooperation and national regulation of participating countries' economies. On the contrary the second one gets an opportunity to become more acceptable for the APR countries. The CREP Agreement initiated by the PRC follows the norms and rules agreed in the framework of the WTO Agreements. China is for more all-inclusive character of the FTA agreements in the region. It offers to include the spheres of investments, industrial value rights not affecting norms and rules that regulate reforming processes and government administration inside the country. Thus the presence of the FTA agreement in the APR can lead to the growth of Chinese economy at about 2 per cent .

But at the same time the PRC is against the imposition of new rules in the international trade within the framework of the FTA Agreements that de facto aim to interfere the procedure of production or "value chain" depriving national economies with the opportunity to regulate the reproduction process by itself. In this connection a significant change of the whole foreign trade structure will take place including the influence of transport, telecommunication and IT revolution. Traditional interindustry trade turns into intraindustry trade even inside the process of creation a product (in other words it is about forming of production value chains), If a production is a "value chain" then division of labour and international trade actually form appropriate reproduction "networks" based on cooperation.

A new approach to potential implementation of trade ("the FTA+" based on an intergovernmental regulation and partnership) is directed at realization of significant changes in the world trade that will provide a deep impact on the foreign policy.

Initiated by the USA new rules of the world trade are the creation of rules and trade regulation implying the interference in the domestic economic policy. In particular the issues of access to the market and to the ccompetitive environment within one jurisdiction are viewed.

However, a complex approach to the FTA is a set of renewed trade rules realized within the framework of the FTA+. They are concentrated on the trade of tangible products in combination with service trade and the movement of investments. It is not only an agreement modernization of current trade but it also includes an approach to create the so-called system of three-component format: trade, investments and services. Such an approach dominates on conducting "the FTA+ Agreements" in modern conditions. 
The FTA+ format is much more difficult than just the FTA agreement. Firstly, countries with different level of economic development, developed and developing, with different structure of economies and differently directed vectors of development not mentioning the existing systems of values and goal-setting development of national economy of participating countries are included in these agreements. In this connection practice or rush in standards and rules' harmonization can cause more harm than benefit.

Secondly, the nature of reforms of various mega-agreements often touches delicate domestic problems. For example concerning Vietnam it is a role of government enterprises (GE), recommendations of Western experts about their reforming or privatization as government enterprises can get grants and other support from governments and it breaks the rules of fair competition. There are also fears that the GEs can be used by government as an instrument for its political and strategic aims, for example, to hold back the sale of land, raise the prices on raw materials, natural resources and transfer of high technologies to other countries. As a rule such conditions are not put forward in the framework of "the FTA+" and the form of ownership of economic entities stays in an independent authority of participating countries.

According to Chinese and Vietnamese researchers the interests of the GEs and the government do not always coincide. The GEs follow their commercial interests as well as private enterprises do. In fact there is no great difference in saving and dividend payment systems between government enterprises and private enterprises. The reason of higher competitive ability of the GEs is at the level of market monopolization where competition is poorly developed and the GEs are the only actors of monopolistic and oligopolistic market. Consequently the essence of a problem is not in the belonging to the property or its form but in the place of enterprises in the market and at the level of development of ccompetitive environment.

The issue of intellectual property rights' protection is also important for China. It is necessary to balance the protection level of novations and to form encouraging tools of new innovators. In this connection economic cooperation and increasing potential of the "FTA+" should be directed to achievement of agreed goals excluding imposing external rules for independent national countries.

Thus the FTA+ agreement is a set of new rules but they should be thoroughly analyzed and discussed by all participating sides in order not to break aims and tasks governments follow to realize their social and economic policies. 
China understands rapid changes of international trade and mainly supports the reform of trade rules in the relation of value chains and goes from the fact that its companies will stand at the head of these chains in the APR. Due to the value growth of foreign investments in the PRC there is a necessity to reform international rules of investments' movements. But China is careful about the role and functions of the GEs and intellectual property. China got a "defensive" position.

"The FTA+" agreements refer to preferential trade agreements exciting in the framework of the WTO .

Nowadays the AOG (the Agreements of Origin of Goods) between developing countries amount about two-thirds of the total number, about a quarter of the AOG is between developed and developing countries. About half of these AOG are intraregional, the rest are interregional and a part of interregional agreements has been increasing during recent years.

The schemes of deep integration go far beyond liberalization of merchandise and services trade. They are oriented on sudden decrease of nontariff barriers, regulation convergence, on general international standards, on stability issues, on quarrels adjustment and on e-commerce regulation. All these agreements are multilateral . All these AOG are oriented on countries with developed economy and mostly seek for contributing the integration into global value chains.

The EAEU countries follow the course on concluding the AOG that are mostly oriented on traditional approach without interfering the internal economic structure of national economies. It is a plus of these agreements and their acceptability to other countries. However, from other side developing economy of the APR countries waits for the inflow of direct investments and new technologies, innovations from the FTA+ that at the level of developing economy cannot always be realized.

The significant part of trade between partners is duty-free within the framework of the regional AOG. Nowadays about 51 per cent of the world trade is also duty-free based on the most-favored-nation regime. The preferential trade in goods covers only 17 per cent of the world trade. The average tariff of the most-favored-nation regime (the MFNR) was about 4 per cent in 2011. Only 2 per cent of the world trade is realized on the preferential rate over 10 per cent. As a rule the regional AOG do not affect the decrease of tariffs in some sensitive sectors and the agriculture remains protected.

The regional AOG have a tendency to complicate and to intrude standards of the WTO (the agreements of the "WTO+") and go beyond the borders of many-sided agreements of the 
WTO (the WTO-X). It led to the deadlock in the WTO in Doha. Complicated international production networks oriented on deep integration and increase of markets sizes have made a classical approach to tariff liberalization less attractive for the most developed countries as low tariffs are not enough for their role in the world economy.

In that way new format of the regional AOG goes beyond the "WTO+" including such spheres as investments, policy in the field of competition, intellectual property, environmental legislation, movement of capitals, labour rights, quarrel adjustment of state-investors, anticorruption tools, economic cooperation, etc.

According to the experts' opinion multilateralism and regionalism of neo-liberal wing are accepted as complementary of each other as the regional AOG can be strong building blocks in the overall trade liberalization. However, the threat of such an approach is that these regional AOG are oriented on the establishment of economic rules for the activity of economic entities of non-member states of this AOG.

The existing offers about the mega-regional AOG are not acceptable because of the attempts to influence politically or by using the administrative resource on the existing social and political system in Brazil, China, India and other growing economies [2, p. 23]. That is why the FTA agreements or the "FTA+" have a priority. China works only in the terms of its own initiatives, for example, as the RCEP (the Regional Comprehensive Economic Partnership) where the basic rules of the WTO remain. India wants to perceive a political space in support of its agriculture and to get an access to markets of some service sectors but it understands that it will not get many concessions in modem conditions. Taking into account the geographical position Brazil is one of the major economic powers that has a real interest in Doha Round especially in agriculture. Nevertheless, it realizes that there are not so many hopes that the price of mega-regional agreements for national economy will be very high and incommensurable with the level of potential benefits.

The policy of India in relation to the signing of the FTA India-Australia is a confirmation of the above-mentioned point of view.

The India-Australia agreement about the all-around economic cooperation (or the free trade agreement) was in danger to breakdown.

According to the Australian government the problem is a migratory policy of India. If Australia resets to zero agricultural and resource tariffs cancelling quotas in the international trade then India seeks to eliminate barriers for mobility of labour power taking it as a priority 
of the first order saving level of safety for the national market and producers acceptable for national interests.

The visa reduction for qualified workers and unwillingness to shorten the time required to issue visas with lower prices, eliminating bureaucratic barriers and hard demands for knowledge of the English language are all taken as barriers for mobility of labour power in Australia. Taken measures in the complex is a significant toughening for skilled migration policy during recent two years. About 25 per cent of all migrants in Australia are the Indians who mainly work in the IT industry. India is in the position that richer countries should provide conditions for better access of Indian labour power on its labour markets. India remains the major country who gets remittances characterized for receiving country.

Australia was one of the most open and developed countries in relation to migration. This policy led to the fact that a part of foreign residents became 29 per cent. It is two times higher than in the USA or in the United Kingdom. The Indian requirements go beyond the borders of the WTO agreements. Australia offers to India to raise a part of students studying in the universities of Australia. However, for India a problem is in the fact that those who have received education return back to the country as practice shows that in future 80 per cent of all students stay to work in the country where they have got education. Thus balancing of migration policy as a tool of internal political imperatives and economic reasons are a barrier for quicker signing the FTA+ agreement in the framework of the APR as these countries have a high growth of population and early start of work activity .

Most members of the WTO do not have an economic clout and abilities to influence on novations in the field of the world trade regulation. According to Perskaya V.V. multilateralism based on interstate agreements is quite a complicated process in conditions of increasing role of national governments in the world community. That is why it gives way to regional agreements on the base of interstate in the form of the AOG or "the FTA+" (Perskaya, 2017, p. 23).

Modern economic policy of developed countries does not anymore rely on many-sided approach in the framework of the WTO to promote its economic interests even in the USA: the priority is given from mega-regionalism to two-sided agreements by the president of the USA D. Trump.

There is a debate among experts on international cooperation issues. It is about how mega-deals and other large and exclusive agreements influence on the many-sided trade regulation. 
Some members of the WTO think that such deals are predecessors of many-sided liberalization when others consider that they ruin the system as a whole. However, one undeniable effect is present. Mega-deals negatively influence on the position of population in the countries with low income level. The developed countries considering themselves economic heavyweights are not ready to make concessions within the framework of the WTO in relation of "other" countries and try to get maximum possible from mega-deals. At the same time an expert community has the same opinion that mega-agreements will be de facto or de jure extended to the rest part of the world community.

As a result the WTO follows the position that a rulemaking cannot be outside the WTO. The process of power establishment of large countries above others and imposing them rules that do not respond to the existing agreements are not acceptable by the modern world economy. At the same time the openness of the foreign trade turnover should be preserved. The collapse of the TTP or the Transatlantic Trade and Investment Partnership (TTIP) does not solve a problem of building foreign economic interaction on fair and overall base for all countries in the world.

In this connection there is a suggestion to create a platform under the WTO's aegis that will promote the increase of cooperation in the field of many-sided base regulation. Such a platform will increase the awareness about harmonization and mutual confession of standards and norms on many-sided basis.

The second suggestion is to strengthen the existing mechanism of transparency for regional trade agreements and to improve collection and expansion of information about regional trade agreements.

The role of regional trade negotiations in the APR was reduced a little bit the past years. Nowadays, it is again increasing. This phenomenon can be explained by two main factors including the disappointment of a slow regulation reform of global trade noting a practical failure of Doha Round negotiations and questioning the legitimacy of the WTO as a whole. That is why the rate of the RTS is an instrument that completes a global system of regulation within the framework of the WTO and substitutes it in some fields. An export is one of the main moving forces of the country economic growth in the APR. The USA's suggestion to conclude the TPP due to informational agitation got a preference to promote the mega-agreement to the detriment of practically agreed and implemented RTS.

In the result of the RTS the agreements on the free trade started to transform and their number started to grow. The sphere of their use expanded and included services, state 
procurements, labor legislation, protection of the environment and intellectual property rights. Higher standards started to be discussed and higher degree of coordination of internal policy started to be agreed. As a result the problems and aims of geopolitics started to influence on the economy and to substitute purely items of the RTS by principle tasks of geopolitics of some countries in the APR.

Researchers from the Peterson University of international economy and from the Center "East-West" give quite pessimistic chances to mega-regional agreements in modern conditions. Particularly two-sided trade of the PRC with the APR countries accounts about 31 per cent of all foreign trade based on international law and the WTO agreements.

The closing of the FTA in the APR with limited members has a negative effect on the efficacy of value chains in this region. In particular the APR countries consider the regional trade agreements to be more acceptable under the APEC aegis, so the APEC can become a platform for coordination and cooperation on wide range of issues. Creation of mega-area of free trade in the APR matches China's own interests and it will meet the tasks of strengthening the regional integration.

Negotiations in the APR on creation the FTA open new opportunities and challenges for all countries including Russia. For example, China is afraid that its FTA economy in Shanghai starts to open such spheres for foreign investors as investing infrastructure, science researches and developments in real sector and transport. Such developments agree with current program of reforms in China. There are several experimental projects for yuan internationalization in the Modern Service Area in Shenzhen. Other FTAs (in Tianjin, Zhejiang and Guangdong) also should lead the process of opening their spheres for foreign partners to get maximum advantages from the FTA in the APEC.

The main partner of Vietnam is Russia. It accounted 90 per cent of transaction of total trade in Vietnam with the EAEU countries in 2013, 92 per cent of Vietnamese export in these countries and 86 per cent of import from them .

The Vietnamese trade turnover with Kazakhstan and Belarus is far less being almost the same in volume. The SRV does not almost support trade relations with Armenia and Kyrgyzstan. The SRV has a stable positive balance up to 1.1 billion of dollars in trade turnover with all countries of the EAEU. At the same time the statistics of the EAEU countries differs from the UNO statistics. Among the favorable factors established by the FTA are the compatibility of the trade export structure of the EAEU countries and the SRV and its noncompetitiveness in other world markets. The economic socialization of the SRV and the export 
of the EAEU complete each other and tough competition is possible only in certain fields that are protected under the agreement. It guarantees a balance of interests of the sides in mutual trade satisfying production requirements and preserving the established traditions of cooperation.

At that, the liberalization of trade in "the FTA+" does not imply significant risks for economies of the EAEU countries as import from Vietnam accounts for about 1 per cent of the total EAEU import from the third countries. The basic mass of which are goods that are not produced on the EAEU territory in the necessary quantity.

The FTA between the EAEU and Vietnam is based on the cooperation for long decades between the USSR and the SRV. The growth of mutual trade is a reestablishment of connections and the evidence of entrepreneurs' interest to support and to develop the mutually beneficial cooperation. In this connection the simplification of conditions and taking away trade barriers are a consistent step of cooperation.

The preparation process of agreements took more than five years in total. The choice of Vietnam by the EEC of the EAEU as the "first" partner on FTA+ is connected with stable and high economic dynamics of the SRV (the growth of the GDP of 6 per cent and more per year), its size - the GDP according to the PPP (the Purchasing Power Parity) reached five hundred billions of dollars that is the thirty second place in the world, foreign trade turnover is more than three hundred billions of dollars, the total volume of the FDI (the foreign direct investment) is more than two hundred forty billions of dollars. At that, the SRV's influence on the APR is growing and the SRV has an experience of signing and realizing of similar RTS and AOGs. The FTA agreement is a "pilot" project for the EAEU which can be spread to all countries of the ASEAN.

According to Vietnamese side all 15 articles (187 points) covered possible forms of cooperation. They are open and transparent and meet the norms of the WTO. They regulate trade terms, rules of origin of goods, actions for trade protection including technical barriers, phytosanitary, veterinarian and other control for products and goods' safety and also simplification of custom duties, approaches to settle legal disputes, etc. The sides determined the directions of cooperation in the field of stable development, e-commerce, public procurements and set common rules for protection the fair competition.

This Agreement differs from deeper forms of integration of the custom or economic union type. The Agreement protects intellectual property including regulation of objects of copyrights and neighboring rights, trademarks, geographical indications (the names of places 
of goods origin), inventions, industrial models, etc. Besides there is a harmonization of normative and legal regulation of the SRV and the EAEU countries to create effective mechanisms for rights protections of the objects of intellectual property. We think it is not correct to speak about harmonization, it is better to put a question about synchronization of legal approach.

The mentioned agreement of the FTA+ gave a strong base for trade regulation increasing predictability of trade policy measures allowing to start coordinating the measures of corresponding state services.

For example, the sides will inform each other about changes in trade regulation beforehand. They will adjust regular cooperation in the sphere of statistical records, document control, technical control and etc.

An electronic system of information change between custom services is provided. It helps to fight with false declaration, customs' value understating and other anti-competitive actions (Vikhlyaev, 2015, p. 161). However, complicated bureaucratic procedures, imperfect legislation, economic criminalization, corruption are factors that threaten the safety of an individual and society, they are barriers for fair competition from business side and economic development of the EAEU countries. However, in the framework of the EAEU there is an illegal movement of goods and other items from the government borders of state-members and customs border of the EAEU "that is a common and socially dangerous action because there is a harm or threat to budget systems and national producers of the EAEU state-members reducing competitiveness of their goods (by evasion from customs payment, use of foreign trade operations for legalization (laundering) criminal income, social security and population health (by illegal movement of drugs, psychedelic and other substances, firearms, bad-quality goods and so on), national security, security of national community (by illegal import and export of extremist literature, weapon of mass destruction including materials and equipment used for its creation, use of foreign trade operations for financing the different criminal activity), culture interests (by illegal export of cultural values)" (Vikhlyaev, 2015, p. 161).

There is a great amount of shadow schemes in foreign trade connected with evasion from customs payment which will be spread on the FTA+ agreement as workers of the FCS (Federal Customs Services) expect (Vikhlyaev, 2015, p. 163).

According to the SRV the FTA agreement between the Eurasian Economic Union and Vietnam is oriented to help the Vietnamese companies to compete equally on the Russian markets by cancelling tariffs (5.63 per cent nowadays). According to the FTA agreement 95 per 
cent of imported tariff lines of Vietnam's export (mostly seafood) are exported to the EEU countries and they will be abolished within ten years but 71 per cent of tariff lines are abolished by the year the Agreement comes into force. As to textiles and clothes 95 per cent of tariffs will be reduced or reset to zero and 42 per cent of them within 10 years. It is a characteristic that Vietnamese side evaluates this Agreement as "the FTA+" or the FTA. As to shoes 77 per cent of tariffs are reduced or zeroed and 73 per cent are abolished within nearest five years. "In its turn Vietnam will use zero duties on beef, dairy products, preserved fish, flour, cereals and also on pipes, rolled steel, asbestos, ships, petrochemicals and many other goods lines ". A duty on petrol will be reduced from 19 to 0 per cent in transition period, on cables - from 20 to 0 per cent within 10 years, on heavy motor trucks - from 17 to 0 per cent.

Partially Vietnam liberalizes access to tobacco goods' market from the EAEU while automobile companies from the EAEU will be in condition of exclusive access on the Vietnamese market. It is considered that the growth of trade will be increased for 10 billion of dollars by 2020 which is a minimum, but it can be increased also ifor 15-20 billion of dollars .

Energy-related projects and military technical cooperation take a great part in the evaluation by the Vietnamese side of the positive results from the realization "the FTA+". At the same time the Vietnamese private investors became interested in food-industry in Russia. The Vietnamese largest producer of dairy products invests 500 million of dollars (on the first phase) into the production of the Russian Federation expecting to get the first part of dairy products in the middle of 2017. The company will invest about 2.7 billion of dollars in three stages within 10 years. The producer hopes to have not only his own herds, milk processing but also to create a chain store system in the Russian Federation (300) which is called "True market". The same investor signed a contract in Kaluga Region with the goal to build three dairy farms with more than 190 million of dollars. Vietnamese fish producers hope to fill up the gap made by the Western prohibition of seafood and fish supply including the Norwegian elk and the Northern Atlantic cod and mackerel. Local Vietnamese producers increased their reserves of pangasius in Russia trying to get 51 per cent of stocks of Russian fish holdings .

However, it should be noted that the SRV prepares to sign the Agreement about the FTA with the European Union that has come into force. From one side it is a direction to reduce a budget deficit but from the other side its aim is to increase the competitiveness of the country in conditions of the free trade with the EU. At the same time the government realizes a program of alienation after privatization with continuing process of government facilities. It is a leading dairy company of the country "Vinamilk" and two largest breweries "Habeco" and "Sabeco". 
For acceleration this process the government of the SRV decided to reduce the percentage of the state to the point less than 50 per cent in 106 government enterprises by 2020 . The National Wealth Fund of Vietnam and State Capital Investment Corporation started to realize a plan to get rid of 137 government enterprises by the end of 2017. Wishing to stimulate the FTA agreement with the EU the SRV realizes a diversification of private sector of the country and transfers all economic segments on the competitive base. According to the SRV the most reliable way to achieve this goal is to create a private sector by giving all the state interests to enterprises' ownership. Private enterprises should increase their competitiveness. Government ownership in enterprises is deterioration in the economy that restricts integration. The SRV should concentrate attention on the development of mechanisms interaction between politicians and leaders of business community and on trainings for business. At the same time the role of the government of the SRV should be in supporting the Vietnamese enterprises of the private sector by forming the channels for products' sale, supporting and promoting national brands in the EU but it should not try to control them at microlevel. From the above mentioned the important science and practical issue is the analysis and forecasting the foreign trade between the EAEU and Vietnam and also the evaluation of economic effectiveness of the free trade agreement between them. Let's view the main approaches to solve this problem developed by modern science literature.

\section{Research Results}

The result of the research was to make a gravity model of the analysis and forecasting the foreign trade in the FTA. As a base of the model the authors used a gravity model described by H. Linneman:

$$
\mathrm{TP}_{\mathrm{ij}}=\mathrm{K}\left(\mathrm{V}_{\mathrm{i}}\right)^{\alpha}\left(\mathrm{V}_{\mathrm{j}}\right)^{\beta}\left(\mathrm{H}_{\mathrm{i}}\right)^{\gamma}\left(\mathrm{H}_{\mathrm{j}}\right)^{\mu}\left(\mathrm{D}_{\mathrm{ij}}\right)^{\tau}+\varepsilon
$$

Where - a trade flow from country $\mathrm{i}$ to country $\mathrm{j} ; \mathrm{Vi}, \mathrm{Vj}$ - the indices that characterize the nominal GDP of corresponding countries; $\mathrm{Hi}$ and $\mathrm{Hj}$ - a number of population in the country; Dij - physical remoteness of economic centers of the country i and j; - elasticity's coefficients of export replacement from the GDP of exporting country, import from the GDP of importing country, number of population of the country $i$, number of population of the country $\mathrm{j}$, from the distance between countries; $\mathrm{K}$ - free term of equation; $\varepsilon$ - random error.

We built a gravity model of foreign trade flows of the participating-countries in the Agreement. We have to answer the questions: how the conditions of the Agreement have 
influenced on trade flows of the participating countries and what the potential of the free trade area is at the existing level of integration.

There is a significant disadvantage in the theoretical gravity model. Variables that characterize the specificity of relations between participating-countries are not taken into account. These participating-countries can have a great influence on the foreign trade amounts. The more the gravity model has variables that describe the peculiarities of the export and import relations and their influences, the more precise the evaluation of foreign trade relations between countries is.

Let us transform the gravity model of the international trade with reference to the conditions of the created free trade area filling up the basic gravity model with set of variables that reflect the country membership to the free trade area and presence of additional conditions in the framework of the Agreement.

$$
\mathrm{TP}_{\mathrm{ij}}=\mathrm{K}\left(\mathrm{V}_{\mathrm{i}}\right)^{\propto}\left(\mathrm{V}_{\mathrm{j}}\right)^{\beta}\left(\mathrm{D}_{\mathrm{ij}}\right)^{\tau}\left(\mathrm{S}_{\mathrm{ij}}\right)^{\varphi}\left(\mathrm{G}_{\mathrm{ij}}\right)^{\omega}+\varepsilon,
$$

Where Gij - trade preferences between countries. The number of preferences is determined by the internal legislation or additional interstate agreements; $\mathrm{Sij}$ - a variable that determines the fact of country participation in the free trade area; - coefficients of elasticity according to the factor of fulfillment the agreement conditions and trade preferences.

We should note that this model shows the connection of variables within one year $(t)$. Taking the logarithm of the model helps analyze the received results more comfortable in future:

$$
\ln T P_{i j}(t)=\kappa(t)+\alpha \ln V_{i}(t)+\beta \ln V_{j}(t)+\tau \ln D_{i j}(t)+\varphi S_{i j}(t)+\omega G_{i j}(t)+\varepsilon_{i j}(t)
$$

The task before us is to study the process in time period from 2014 to 2017 . When evaluating the model it is reasonable to accept the evaluation assumption of the "fragmentary data" which means to study the data corresponding to certain years: $\mathrm{t}=2014,2015,2016,2017$. A certain fixed year $\mathrm{t}$ will allow to exclude a temporal parameter from the model:

$$
\ln \mathrm{TP}_{\mathrm{ij}}=\kappa+\alpha \ln \mathrm{V}_{\mathrm{i}}+\beta \ln \mathrm{V}_{\mathrm{j}}+\tau \ln \mathrm{D}_{\mathrm{ij}}+\varphi \mathrm{S}_{\mathrm{ij}}+\omega \mathrm{G}_{\mathrm{ij}}+\varepsilon_{\mathrm{ij}}(4)
$$

It is necessary to accept the assumptions about the signs of coefficients of variables for computation the gravity model.

We think that the following coefficients will be positive:

, - because all the countries signed the Agreement about the free trade area and they have certain trade potential. The size of the exporting country's economy corresponds its production abilities and has a positive influence on the trade flow volume directed or poetically 
directed to the country of destination. The size of the importing country's economy characterizes the domestic market and reflects a demand on the imported goods as a result of it we expect that imported trade flow is bigger than the importing country's economy.

- as there is the Agreement in the free trade area;

- we think that existing normatively fixed conditions to realize services and direct investments stimulate their volume.

A negative sign will have a coefficient as when distances between economic centers of the country increase, the transport expenses grow. We think that distance increasing between partner countries will significantly reduce the attractiveness of goods because of exceeding the costs of transportation over the effect of preferences of the free trade area.

We will view export and import flows in the research fixing only one country. In this case we will have to evaluate empirical evidences on each country that are in the free trade area Agreement: Russia-Vietnam, Belarus-Vietnam, Kazakhstan-Vietnam, Armenia-Vietnam, Kyrgyzstan-Vietnam.

We will get the gravity control to the exporting country:

$$
\ln \mathrm{TP}_{\mathrm{i}}=\kappa+\beta \ln \mathrm{V}_{\mathrm{i}}+\tau \ln \mathrm{D}_{\mathrm{i}}+\varphi \mathrm{S}_{\mathrm{i}}+\omega \mathrm{G}_{\mathrm{i}}+\varepsilon_{\mathrm{i}}(5)
$$

If we accept random movements that do not depend on the then for realization of the model the method of the least squares will be more optimal

Considering trade between participating countries of the Agreement we should take into account that value of export and import between countries is not homogeneous.

For empirical evaluation of the model we viewed aggregated product groups that occupy the biggest part in the trade structure between participating countries of the Agreement and the SRV: machinery and equipment, metal and products from it, chemical industry production, food products and agricultural raw material and wood. Services are in a different group.

This fact influences on the gravity model to which we add fictional variables. They characterize foreign trade structure:

$$
\begin{aligned}
& \quad \ln \mathrm{TP}_{\mathrm{j}}=\kappa+\beta \ln \mathrm{V}_{\mathrm{j}}+\tau \ln \mathrm{D}_{\mathrm{j}}+\varphi \mathrm{S}_{\mathrm{j}}+\omega \mathrm{G}_{\mathrm{j}}+\pi \mathrm{A}_{\mathrm{ij}}+\psi \mathrm{T}_{\mathrm{ij}}+\mathrm{xM}_{\mathrm{ij}}+\mathrm{cN}_{\mathrm{ij}}+\mathrm{kL}_{\mathrm{ij}}+ \\
& \rho \mathrm{E}_{\mathrm{ij}}+\lambda \mathrm{Q}_{\mathrm{ij}}++\varepsilon_{\mathrm{j}}(6)
\end{aligned}
$$

where - a variable defining volume of foreign trade turnover of machinery and equipment; - a variable defining the volume of foreign trade turnover of metal; - a variable defining the volume of foreign trade turnover of chemical industry production; - a variable defining the volume of foreign trade turnover of food products and agricultural raw material; 
- a variable defining the volume of foreign trade turnover of wood; - a variable defining the volume of services export; - a variable defining the volume of investments; - coefficients of elasticity of export and import of corresponding groups of goods, services and investments.

Analyzing the trend of development of trade turnover of Vietnam export operations to participating-countries of the Agreement we can suppose that the country does not enough use its potential being an exporting country to Russia. It is also connected with one very important factor such as quality of goods. For instance, food products and agricultural raw material do not correspond with State Standard (GOST) and Requirements Specification that Russia has for foreign trade. To assess the impact of the quality factor of goods let us introduce one more fictional variable and coefficient of elasticity of goods quality - $\chi$. As the variable of goods quality influences on reducing the trade flow we think that the sign of coefficient $\chi$ is negative in the model.

The gravity model will have the following form:

$$
\ln \mathrm{TP}_{\mathrm{j}}=\kappa+\beta \ln \mathrm{V}_{\mathrm{j}}+\tau \ln \mathrm{D}_{\mathrm{j}}+\varphi S_{j}+\omega \mathrm{G}_{\mathrm{j}}+\pi \mathrm{A}_{\mathrm{ij}}+\psi \mathrm{T}_{\mathrm{ij}}+\rho \mathrm{E}_{\mathrm{ij}}+\lambda \mathrm{Q}_{\mathrm{ij}}+\chi U_{\mathrm{ij}}+\varepsilon_{\mathrm{j}}
$$

We should pay attention on the gravity effect of distance from point of goods destination. We made a clause in the model that points of destination are the capitals of countries. However, we should take into account when increasing the distance between points of goods destination and complication of routes a coefficient of destination variable will be increased with negative sign and it will confirm an effect of costs growth for transportation and reducing of trade flows as a result.

The observed model can be used for analysis of export and import flows between countries who do not participate in the Agreement. In this case the accounting of variable impact of and is rational. In our research all countries are participants of the Agreement that is why the empirical evaluation of variables and are included into free member of equation

$$
\ln \mathrm{TP}_{j}=\kappa+\beta \ln V_{j}+\tau \ln D_{j}+\varphi S_{j}+\omega G_{j}+\pi \mathrm{A}_{i j}+\psi \mathrm{T}_{i j}+\rho \mathrm{E}_{i j}+\lambda Q_{i j}+\chi U_{i j}+
$$

If we accept occasional inconsistencies that do not depend on the then the most optimal method will be the method of least squares for model realization.

Statistical facts on the volume of export and import cover the period from 2014 to 2017 and they are dollar-denominated. The following sources were used for gathering the statistical facts: the official web-site of the United Nations Organization (http://unstats.un.org); the official web-site of the World bank (www5.worldbank.org); the official web-site of the 
Eurasian Economic Commission (www.eurasiancommission.org); the official web-sites of the Vietnam Government; the State Customs Service of Vietnam; the State Service of Statistics of Vietnam; Ministry of Planning and Investment of Vietnam (http://www.mpi.gov.vn); agreements in force between Russia and Vietnam in trade and economic spheres in 2017; materials about Russian and Vietnamese trade, trade and economic cooperation between Russian Federation and Vietnam; export strategy of Vietnam for the period 2011-2020.

The created gravity model is supposed to be used for analyzing export and import flows of participating countries of the free trade area agreement with Vietnam. It is an econometric model (in a logarithmic form). We make private gravity models for each year for export flows into Vietnam and import flows from Vietnam.

A special script in the language $\mathrm{R}$ was developed for building models. It is executed in the same environment. The algorithm of building contains the following steps: 1) initial data input; 2) calculation of gravity models for each year; 3) information output.

The initial data base are formed at the first step, they are used to calculate models. The data base contain information about countries' GDP (variable V), distance between capitals (variable D) and foreign trade turnover divided into the import from Vietnam and export into Vietnam (variables TPimport and TPexport). The variables countryName and yearName indicate countries and years when the calculation of models was gone.

The calculation of gravity models for import and export for each year takes place at the second step. The function $1 \mathrm{~m}$ is used for building the model at this step in the form of $\log (\mathrm{TP}) \sim \log (\mathrm{V})+\log (\mathrm{D})$ where TP is a vector that indicates trade turnover for calculated year, $\mathrm{V}$ is a vector that contains countries' GDP for calculated year, B is a distance between capitals. A result for fitting the models is saved in variables dfExport and dfImport for export or import into and from Vietnam.

At the third step the data are derived from variables dfExport and dfImport, diagrams of meaning of elasticity coefficient for the GDP and a characteristic of model's relative precision.

\section{Discussions Of Scientific Results}

The analysis of development of integration trade connections between the EAEU and Vietnam shows that the FTA Agreement which is in force towards the integration between 
Russia and the SRV is a quite effective tool for development of the trade relations between countries.

Trade flows have a tendency to grow. Nevertheless, the integration of the SRV based on development of foreign trade cooperation and cooperation partnership in a number of segments of a real sector has quite weakly expressed character.

Analyzing the results of calculation on a variable that characterizes the export from the EAEU countries to Vietnam of a group of goods that refer to our classification of machinery and equipment we can note the following tendency which is a typical to all participating countries in the Agreement: after signing the Agreement in 2015 the export indices sharply increased (10 per cent in Russia, 66 per cent in Belarus, 52 per cent in Kazakhstan, 34 per cent in Kyrgyzstan, 7 per cent in Armenia). The same tendency we observe in 2016 and during the first half of 2017. The variable that characterizes import of machinery and equipment to the EAEU countries from Vietnam has also a tendency of stable growth and characterizes the increase of indices after 2014 in the FTA agreement. The growth of import was 10 per cent in Russia, 32 per cent in Belarus, 32 per cent in Kazakhstan, 9 per cent in Kyrgyzstan, 2 per cent in Armenia in 2015. The calculation data in 2016 show a character of tendencies' instability. The import of a group of goods referring to machinery and equipment decreased by 27 per cent in Russia while there was the import increase in other countries (32 per cent in Belarus, 32 per cent in Kazakhstan, 9 per cent in Kyrgyzstan, 2 per cent in Armenia). The data in 2017 show again positive dynamics of import increase from Vietnam to all participating countries of the Agreement.

Analyzing the data on variable that characterizes export from the EAEU countries into Vietnam of a group of goods referring to our classification of metal and products from it we note the following tendencies: the export of goods of this group into Vietnam from all EAEU countries increases from 2014 to 2017 . The size of volume growth differs and in comparison with 2014 it is 36 per cent for Russia in 2015, 40 per cent in 2016 and 88 per cent in the first half of 2017; 1 per cent for Belarus in 2015, 10 per cent in 2016 and 11 per cent in the first half of 2017; 72 per cent for Kazakhstan in 2015, 91 per cent in 2016 and 93 per cent in the first half of 2017; 49 per cent for Kyrgyzstan in 2015, 58 per cent in 2016 and 62 per cent in the first half of 2017; 10 per cent for Armenia in 2015, 11 per cent in 2016 and 12 per cent in the first half of 2017. The Variable that characterizes import of group of metal and products from it from Vietnam to the EAEU countries conducts itself differently taking various values by countries. In comparison with 2014 there is a growth of variable's value for 10 per cent in 
Russia in 2015. However, in comparison with 2014 there is a decrease of import volumes for 9 per cent in 2016. In comparison with 2014 there is a growth of variable's value for 55 per cent in the first half of 2017. The same tendency is for Belarus. There is a growth of import for 35 per cent in 2015, decrease for 80 per cent in 2016 and a growth of import for 53 per cent in the first half of 2017. As for Kazakhstan, Kyrgyzstan and Armenia there is a stable increase of import.

Analyzing a variable's value that characterizes export of chemical industry production for the EAEU to Vietnam we should note the growth of variable's value in all countries during the whole analyzing period. However, while analyzing a variable's value that shows a dynamics of import value to the EAEU countries from Vietnam we observe a reduce of indices for 9 per cent in Russia in 2016 (though there was an increase of indices for 9 per cent when the Agreement came in force in 2015). As to other countries of the EAEU there is a stable import growth little by little.

Viewing a variable that characterizes export of food products and agricultural raw material we should note the following results: this group of goods is the largest in a big export group of goods. It is typical for all EAEU countries. The results of calculation show the stable growth of a variable's value that indicates an export growth during the whole period the Agreement is in force. Completely another tendency we view analyzing variable that characterizes an import of food products and agricultural raw material from Vietnam to the EAEU countries. There was an import growth during the first year the Agreement came in force in 2015. The situation was changed in 2016 and an import to Russia decreased for 5 per cent regarding to 2014 and then for 17 per cent in the first half of 2017 regarding to 2014. This tendency is connected with a quality of production that is taken in the model as a negative value which reduces the volume of turnover.

To reduce the influence of this negative factor it is necessary for the Vietnamese side to take into consideration the requirements of the State Standards and Requirements Specification on goods. There is a small growth of variable from 3 per cent to 7 per cent in other countries of the EAEU.

Viewing a variable's value that reflects export of wood we should note a positive influence of the Agreement on export of this group of goods into Vietnam. There is a stable growth of turnover in all countries of the EAEU. As to import there is also a general tendency but with an inverse effect: the decrease of variable that shows the decrease of the import of wood from Vietnam to the EAEU countries. 
The analysis of variable's value that characterizes the value of export of services shows the following results: when the Agreement came in force the volume of given services for export increased in all countries of the EAEU. A high growth was in 2016. The same tendency in increasing shows a variable that characterizes import of the Vietnamese services to the EAEU countries.

The built gravity model can be used for analyzing the development of foreign trade connections with the EAEU countries. The received coefficient values correspond to stated theoretical suppositions and describe the main tendencies of development of the foreign trade between the EAEU and Vietnam and describe the dynamics of integration processes.

\section{Conclusions}

The research allows to make the following conclusions:

1. According to the built gravity model based on the author's algorithm it is proved that the FTA Agreement is a quite effective instrument for development of trade relations between countries. Trade flows have a tendency to increase. Nevertheless, the integration of the SRV based on the foreign trade cooperation and cooperation partnership in a number of segments of a real sector has a quite weekly expressed character.

2. Taking this into account the authors offered to expand the agreement on the FTA between state-members of the EAEU and Vietnam including in it provisions about creating conditions for effective banking service of this international trade model. Methodology and selection criteria of credit institutions for deposit and settlement services of Eurasian and Vietnamese trade and economic cooperation should be developed meaning a parallel adaptation of operational and organizational bank models to economic relations in the FTA.

\section{REFERENCES}

1. Douglas, G. (2017). Labour migrants from Kyrgyzstan, Tajikistan and Uzbekistan to Russia amidst uncertain trends. URL: https://www.stratfor.com/article/labour-migrantskyrgyzstan-tajikistan-and-uzbekistan-russia-amidst-uncertain-trends

(accessed 2.09.2017).

2. Lee, H. W., \& Tseng, H. K. (2016). Preferenciating Global Free Trade: A coevolving network model of free trade negotiation.

3. Perskaya, V. V. (217). Free trade or protectionism determine the future of regional and economic associations. Foreign trade and trade policy, 3, 23-49. 
4. Vikhlayev, A. O. (2015). Factors that influence on illegal movement of goods form state borders of the EAEU state-members and customs border of the EAEU. Law and right, $10,161-167$.

5. About the results of foreign trade of the EAEU. The official web-site of the EAEC. URL: http://www.eurasiancommission.org/ru/act/integr_i_makroec/dep_stat/tradestat/analyti cs/Documents/ (accessed 28.08.2017).

6. The results of foreign trade of the EAEU with the third countries. The official web-site of the EAEC URL: http://www.eurasiancommission.org/ru/act/integr_i_makroec/dep_stat/tradestat/tables/ extra/ Documents/ (accessed 30.08.2017).

7. Perskaya, V. V., \& Dzhagityan, E. P. (2017). Peculiarities of post-crisws vectors of direct foreign investments of the APR countries. Finances and loan : theory and practice, 6, 80-93.

8. Ludema, R. D. (2002). Increasing returns, multinationals and geography of preferential trade agreements. Journal of International Economics, 56(2), 329-358.

9. Baier, S. L., \& Bergstrand, J. H. (2007). Do free trade agreements actually increase members' international trade?. Journal of international Economics, 71(1), 72-95.

10. Moser, C., \& Rose, A. K. (2014). Who benefits from regional trade agreements? The view from the stock market. European Economic Review, 68, 31-47.

11. Goyal, S., \& Joshi, S. (2006). Bilateralism and free trade. International Economic Review, 47(3), 749-778.

12. Amiti, M., \& Romalis, J. (2007). Will the Doha Round lead to preference erosion?. IMF Staff Papers, 54(2), 338-384.

13. Gallagher, K. P. (2007). Understanding developing country resistance to the Doha Round. Review of international political economy, 15(1), 62-85.

14. Russian and Vietnamese economic forum was held in Moscow within the framework of the visit of the Vietnam's President. URL: https://invest.primorsky.ru/newspage/rossiisko-v-etnamskii-ekonomicheskii-forumproshel-v-moskve-v-ramkakh-vizita-prezidenta-v-etnama/?lang=ru-RU (accessed 25.08.2017).

15. Foreign trade between Russia and Vietnam in 2007-2016. The official web-site of the RF Ministry for Economic Development. URL: http://economy.gov.ru/wps/wcm/connect/26881324-15f9-4e25-b58d2f55c3cb1a13/8.pdf? MOD=AJPERES\&CACHEID=26881324-15f9-4e25-b58d2f55c3cb1a13c (accessed 10.08.2017).

16. Panteleeva, O. I. Revenko L.S., Akkanina N.V., Romanyuk M.A. Panteleeva O.I., Revenko L.S. (2017). Regulation of export of agricultural goods in Russia and abroad: monograph. Moscow, Economika Publ.

17. The official web-site of the RF Ministry of Agriculture. URL: http://mcx.ru/activity/state-support/programs/program-2013-2020/ (accessed 14.08.2017). 
18. Vinkenborg, M. (2017). Vietnam in 2017: Spotting opportunities for FDI. URL: http://www.vietnam-briefing.com/news/author/vietnam-briefing 15.08.2017).

19. Vinatex seeks investment opportunities in Armenia. URL: https://www.vietnambreakingnews.com/2017/09/vinatex-seeks-investmentopportunities-in-armenia/ (accessed 04.09.2017).

20. UNCTAD (2017). Investment policy monitor, Issue 17, March. URL: http://unctad.org/en/PublicationsLibrary/webdiaepcb2017d1_en.pdf 27.08.2017).

21. Vietnam country commercial guide. URL: https://www.export.gov/article?id=Vietnam-Openness-to-Foreign-Investment (accessed 13.09.2017).

22. U.S. Department of State. Diplomacy in action. URL: https://www.state.gov/documents/organization/229305.pdf (accessed 28.08.2017).

23. Nguyen Hong Van. Opening the market for banking services in line with the commitments made by Vietnam on its WTO accession. URL: http://privat.bahnhof.se/wb250067/buongiorno/vietnam/documents/theses/Nguyen\%20 Hong\%20Van.pdf (accessed 25.09.2017).

24. GNI per capita, PPP (current international \$). The source: World Bank, International Comparison Program database. URL: https://data.worldbank.org/indicator/NY.GNP.MKTP.PP.CD (accessed 16.09.2017).

25. Mazyrin, V. M., \& Kobelev, E. V. (2015). Russia and Vietnam : 20 proposals on increasing the effctivness of comprehensive and strategic partnership. Workbook no. 23/2015. Eds. Ivanova I.S. The Russian council on international affairs (the RCIA). Moscow, Special book Publ.

26. Pardee, F. S. (2017). Center for International Futures, University of Denver. URL: http://www.ifs.du.edu/ifs/frm_CountryProfile.asps?Country=VN (accessed 02.09.2017).

27. International Migration Report 2015 Highlights. (2016). New York, United Nations, 6, 18.

28. Ding, H. M. (2015). Social and economic conditions of migration from Vietnam into Russia. Vestnic of Irkutsk State Technical University Publ, 4(99), 251-254.

29. Viet Nam Migration profile 2016. URL: http://publications.iom.int/books/vietnam-migration-profile-2016 (accessed 01.09.2017).

30. The official web-site of International organization on migration.URL: https://www.iom.int/countries/viet-nam (accessed 17.09.2017).

31. Climate change adaption and migration. IOM Viet Nam. 2012, 4 p. (accessed 15.09.2017).

32. The web-site of the Ministery of agrwculture and farm welfare of India http://agriculture.gov.in/ (accessed 8.01.2018) 
33. Government launches 2017/2018 Agricultural and Livestock Plan. URL: http://www.brazilgovnews.gov.br/news/2017/06/government-launches-2017-2018agricultural-and-livestock-plan-1 (accessed 8.01.2018).

34. The web-site of the Vietnamese Center of the WTO. URL: http://wtocenter.vn/news/indiaaustralia-fta-impossible-road-ahead (accessed 29.05.2017).

35. URL: http://wtocenter.vn/news/indiaaustralia-fta-impossible-road-ahead/ (accessed 29.05.2017.

36. GED Mini-Series: Inclusiveness in the Global Trading System. URL: DATA OF THE

\section{SOBRE OS AUTORES:}

\section{E.S. Sokolova}

Doctor of Economics, Professor of the Department of Global Economy and Global Finance, Financial University under the Government of Russian Federation. E-mail: sokolova@mail.ru (iD) http://orcid.org/0000-0002-8535-6393

\section{V.V. Perskaya}

Doctor of Economics, Professor, Director of the Institute for the Research of International Economic Relations, Financial University under the Government of Russian Federation. Email: perskaya@mail.ru

iD http://orcid.org/0000-0003-1691-5013

\section{A.A. Tkachenko}

Doctor of Economics, Professor, Deputy Director of the Institute for the Research of International Economic Relations, Financial University under the Government of Russian Federation. E-mail: tkachenko@ mail.ru

(iD) http://orcid.org/0000-0003-0925-6822

\section{P.V. Alekseev}

Ph.D in Economics, Leading Researcher of the Institute for the Research of International Economic Relations, Financial University under the Government of Russian Federation. Email: alekseev@mail.ru

(iD http://orcid.org/0000-0002-1048-1050

\section{M.A. Rylskaya}

Doctor of Law, Professor.E-mail: rylskaya@mail.ru

iD http://orcid.org/0000-0002-9714-5593 